\title{
A new species of Elasmopus (Amphipoda: Hadzioidea: Maeridae) from Suape Harbor, Northeastern Brazilian coast
}

\author{
ANDRÉ R. SENNA \\ Universidade Federal do Rio de Janeiro, Museu Nacional, Departamento de Invertebrados, Setor de Carcinologia, \\ Quinta da Boa Vista, s/n, São Cristóvão, 20940-040 Rio de Janeiro, RJ, Brasil \\ Manuscript received on January 11, 2011; accepted for publication on February 22, 2011
}

\begin{abstract}
A new amphipod species of the genus Elasmopus Costa, 1853 is described based on material collected from intertidal rocky shore, near the Suape Harbor, coast of the Brazilian state of Pernambuco. The new species may be recognized by the propodus of gnathopod 2 suboval, slightly tapering distally, palmar margin not defined by a stout seta, spine, or palmar corner, with a subdistal blunt tubercle, posterior margin covered by a dense fringe of plumose setae, and posterior margin of basis of pereopod 7 castelloserrate. This is the ninety-fifth species of the genus Elasmopus described worldwide, the most diverse genus in the family Maeridae Krapp-Schickel, 2008, and the eighth species recorded from Brazilian waters. An identification key to Brazilian species of Elasmopus is also provided.
\end{abstract}

Key words: Brazil, Elasmopus souzafilhoi sp. nov., Gammaridea, intertidal, Pernambuco, taxonomy.

\section{INTRODUCTION}

The genus Elasmopus Costa, 1853 is widely distributed in warm and tropical waters of the Atlantic, Pacific, and Indian Oceans, besides the Mediterranean Sea. It is the most diverse genus in the family Maeridae KrappSchickel, 2008. Its species are usually found in shallow waters associated to macrophytobenthos, sponges, zoanthids, and gravel sediments (Souza-Filho and Senna 2009).

Knowledge about the diversity of Elasmopus, such as other amphipod genera in Brazil, is still very scarce. Hitherto, there are only seven valid species of Elasmopus recorded from Brazilian waters, besides the new species described in this work: E. brasiliensis (Dana, 1853); E. fusimanus Oliveira, 1951; E. karamani Souza-Filho and Senna, 2009; E. lejeunei Souza-Filho and Senna, 2009; E. longipropodus Senna and Souza-Filho, 2011; E. pectenicrus Bate, 1862; and E. spinidactylus Chevreux, 1907. Another species, E. besnardi Oliveira, 1951, was synonymized with E. brasiliensis by Barnard (1965).

E-mail: ar.senna@hotmail.com
Fortunately, some recent taxonomic studies have increased our knowledge on the Brazilian hadzioid fauna (Krapp-Schickel and Ruffo 2000, Senna and Serejo 2007, Souza-Filho and Senna 2009, Senna and Souza-Filho 2011).

In this paper, a new species of the amphipod genus Elasmopus with castelloserrate pereopod 7 is described from the vicinity of the Suape Harbor, Pernambuco State, Brazil. There are two other species recorded from Brazilian waters with castelloserrations on the posterior margin of the basis of pereopods 6 or 7: E. pectenicrus, with pereopod 6 castelloserrate, and E. fusimanus, with pereopod 7 castelloserrate. These species are part of a diverse group of almost entirely Indo-Pacific species, with intertropical distribution, that shares the castelloserrate pereopods 6 and 7 (Krapp-Schickel and Ruffo 1990).

\section{MATERIALS AND METHODS}

The material examined was collected by free-diving on October $10^{\text {th }}, 2003$, in Sargassum sp. from the intertidal zone of rocky shore at $08^{\circ} 21^{\prime} 26^{\prime \prime} \mathrm{S}-34^{\circ} 57^{\prime} 22^{\prime \prime} \mathrm{W}$, Suape 
Beach, Santo Agostinho Cape, near the Suape Harbor, Pernambuco State, in the Northeastern Brazilian coast.

All material is preserved in $70 \%$ ethanol and housed at the Crustacea collection of the Museu Nacional, Universidade Federal do Rio de Janeiro (MNRJ). Appendages and mouthparts have been mounted in glass slides with gelatin-glycerol. Illustrations were made under optic microscope with camera lucida and digitally prepared as described by Coleman (2003). They represent the holotype, except when the male and female are indicated in the figure. Setal classification adopted in this paper follows Watling (1989), while the nomenclature of gnathopod palm is based on Poore and Lowry (1997).

The following abbreviations are used on the figures: Hd, Head; A1-2, Antennae 1-2; Mx1-2, Maxillae 1-2; Md, Mandible; Gn1-2, Gnathopods 1-2; P3-7, Pereopods 3-7; Ep1-3, Epimeral plates 1-3; U1-3, Uropods 1-3; T, Telson; $\mathrm{m}$, male; f, female.

\section{SYSTEMATICS}

Order Amphipoda Latreille, 1816

Superfamily Hadzioidea Bousfield, 1983

Family Maeridae Krapp-Schickel, 2008

Genus Elasmopus Costa, 1853

Type-species: Elasmopus rapax Costa, 1853

\section{Composition of the Genus}

The genus Elasmopus groups 95 species: E. aduncus Myers, 1995; E. affinis Della Valle, 1893; E. alalo Myers, 1986; E. antennatus (Stout, 1913); E. arrawarra Hughes and Lowry, 2006; E. atolgidus J.L. Barnard, 1965; E. balkomanus Thomas and Barnard, 1989; E. bampo J.L. Barnard, 1979; E. barbatus Schellenberg, 1939; E. bastidai García-Madrigal, 2010; E. bollonsi Chilton, 1915; E. brasiliensis (Dana, 1853); E. buchneri Spandl, 1924; E. calliactis Edmondson, 1951; E. canarius Krapp-Schickel and Ruffo, 1990; E. caprai Maccagno, 1936; E. chilensis Walker, 1913; E. congoensis Shoemaker, 1920; E. crassimanus (Miers, 1884); E. crenulatus Berents, 1983; E. delaplatus Stebbing, 1888; E. dentiferus Schellenberg, 1938; E. diplonyx Schellenberg, 1938; E. dubius Walker, 1904; E. ecuadorensis Schellenberg, 1938; E. erythraeus (Kossmann, 1880); E. excavatus Schellenberg, 1938; E. fusimanus Oliveira, 1951; E. gracilis Schellenberg, 1938; E. hawaiensis Schellenberg, 1938; E. holgurus
J.L. Barnard, 1962; E. hooheno J.L. Barnard, 1970; E. integer Myers, 1989; E. japonicus Stephensen, 1932; E. karamani Souza-Filho and Senna, 2009; E. karlae García-Madrigal, 2010; E. koreanus Kim and Kim, 1991; E. lapu Myers, 1985; E. laufolii Myers, 1986; E. lecroyae García-Madrigal, 2010; E. lejeunei SouzaFilho and Senna, 2009; E. lemaitrei Ortiz and Lalana, 1994; E. levis (Smith, 1873); E. longipropodus Senna and Souza-Filho, 2011; E. magnispinatus Kunkel, 1910; E. marcelae García-Madrigal, 2010; E. marplatensis Alonso de Pina, 1997; E. mayo J.L. Barnard, 1979; E. menurte J.L. Barnard, 1974; E. minimus Chevreux, 1908; E. molokai J.L. Barnard, 1970; E. mutatus J.L. Barnard, 1962; E. nanshaensis Ren, 1998; E. neglectus Chilton, 1915; E. oaxaquensis García-Madrigal, 2010; E. ocoroni J.L. Barnard, 1979; E. palu Appadoo and Myers, 2003; E. pectenicrus (Bate, 1862); E. perditus Reid, 1951; E. piikoi J.L. Barnard, 1970; E. pilosus Ledoyer, 1978; E. pocillimanus (Bate, 1862); E. pseudaffinis Schellenberg, 1938; E. pseudinteger Appadoo and Myers, 2003; E. pubescens (Dana, 1852); E. puteus Appadoo and Myers, 2003; E. rapax Costa, 1853; E. rishikondiensis Kanakadurga, Rao and Shyamasundari, 1981; E. serricatus J.L. Barnard, 1969; E. seticarpus Myers, 1985; E. slatyeri Lowry and Hughes, 2009; E. souillacensis Appadoo and Myers, 2003; E. souzafilhoi sp. nov.; E. spinibasus Sivaprakasam, 1970; E. spinicarpus Berents, 1983; E. spinidactylus Chevreux, 1907; E. spinimanus Walker, 1904; E. spinipalpus Ledoyer, 1982; E. spinipes Mateus and Mateus, 1986; E. steelei Appadoo and Myers, 2003; E. steinitzi Ruffo, 1938; E. takamotus Myers, 1986; E. temori J.L. Barnard, 1979; E. thomasi Ortiz and Lalana, 1994; E. tiburoni J.L. Barnard, 1979; E. tubar J.L. Barnard, 1979; E. vachoni Mateus and Mateus, 1986; E. vagans K.H. Barnard, 1940; E. varanocephalensis Lowry and Hughes, 2009; E. visakhapatnamensis Kanakadurga, Rao and Shyamasundari, 1981; E. waltersi Ledoyer, 1982; E. wahine J.L. Barnard, 1972; E. warra Kelaher and Lowry, 2002; E. yunde J.L. Barnard, 1974; and E. zoanthidea J.L. Barnard, 1979.

\section{GENUS DIAGNOSIS}

Lateral cephalic lobe short, anteroventral cephalic notch present. Antenna 1 longer than antenna 2, accessory flagellum at least 2-articulate. Lower lip with inner 
lobes present. Mandible, palp 3-articulate, article 1 without ventrodistal spine, article 3 strongly falciform, with $\mathrm{D}$ and E setae. Maxilla 1, inner plate suboval to subrectangular, inner margin not or weakly setose, apical margin with 1-2 plumose setae; outer plate with multicuspidate setal-teeth apically; palp 2-articulate. Maxilla 2 , inner plate facial setal row absent. Gnathopods 1-2 subchelate, different in shape and size (male gnathopod 1 much smaller than gnathopod 2), palms acute to extremely acute. Coxae slightly elongate, coxa 4 with posterodistal lobe rounded to subquadrate. Pereopods 57 usually short and stout, basis with posteroventral lobe present. Uropod 1, peduncle basofacial seta present, rami subequal in size. Uropod 3, rami short, magniramous, apically truncate; outer ramus broad and strongly setose, 1 articulate or with vestigial article 2 . Telson usually deeply cleft.

Modified from Karaman (1982) and Krapp-Schickel and Jarrett (2000).

Elasmopus souzafilhoi sp. nov.

(Figs. 1-4)

\section{MATERIAL EXAMINED}

Holotype: 1 male, $5.9 \mathrm{~mm}$, in glycerin gel slides, dissected and drawn, Praia de Suape, Cabo de Santo Agostinho, Pernambuco State, Brazil, 08²1'26"S$34^{\circ} 57^{\prime} 22^{\prime \prime} \mathrm{W}$, October $10^{\text {th }}$, 2003, intertidal, in Sargassum sp., J.F. Souza-Filho, col., MNRJ 22534.

Paratypes: 1 male, $3.9 \mathrm{~mm}$, in ethanol, Praia de Suape, Cabo de Santo Agostinho, Pernambuco State, Brazil, $08^{\circ} 21^{\prime} 26^{\prime \prime S}-34^{\circ} 57^{\prime} 22^{\prime \prime} \mathrm{W}$, October $10^{\text {th }}, 2003$, intertidal, in Sargassum sp., J.F. Souza-Filho, col., MNRJ 22535; 1 female, $5.7 \mathrm{~mm}$, in ethanol, dissected and drawn, Praia de Suape, Cabo de Santo Agostinho, Pernambuco State, Brazil, $08^{\circ} 21^{\prime} 26^{\prime \prime S}-34^{\circ} 57^{\prime} 22^{\prime \prime} \mathrm{W}$, October $10^{\text {th }}, 2003$, intertidal, in Sargassum sp., J.F. Souza-Filho, col., MNRJ 22536; 3 males, 18 females, and 12 juveniles, in ethanol, Praia de Suape, Cabo de Santo Agostinho, Pernambuco State, Brazil, $08^{\circ} 21^{\prime} 26^{\prime \prime S}-34^{\circ} 57^{\prime} 22^{\prime \prime} \mathrm{W}$, October $10^{\text {th }}$, 2003, intertidal, in Sargassum sp., J.F. Souza-Filho, col., MNRJ 22537.

\section{ETYMOLOGY}

This species is dedicated to Dr. Jesser Fidelis de Souza Filho, from Universidade Federal de Pernambuco
(UFPE), amphipodologist, collaborator in many scientific works, and a good friend.

\section{DIAGNOSIS}

Antenna 1, accessory flagellum 2-articulate. Mandible, palp article 3 robust, about 2.3 times longer than wide. Maxilla 1, inner plate with a row of simple slender setae on the inner margin, and two apical plumose setae. Male gnathopod 2, palm not defined, with a subdistal blunt tubercle, with three small stout setae near hinge of dactylus, posterior margin with a dense fringe of long plumose setae. Pereopod 6, basis with posterior margin smooth but regularly beset with setae, posteroventral lobe weakly developed. Pereopod 7, basis with posterior margin castelloserrate. Epimeral plates 1-2, posterior margin with one or two notches. Epimeral plate 3, posteroventral corner slightly produced and subacute, posterior margin minutely serrate for about one third of the length. Uropod 3, inner ramus thinner and slightly shorter than outer ramus. Telson, wider than long, apically truncate with cusps (male), or inner corner rounded (female), with three subapical stout setae in each lobe.

\section{DESCRIPTION}

Based on holotype male, $5.9 \mathrm{~mm}$. Head with big eyes, rounded to reniform, with distinct ommatidia; lateral cephalic lobes broad, rounded, with anteroventral notch and slit, anteroventral corner rounded. Antenna 1 , densely setose, longer than antenna 2, about half of body length; peduncular article 1 subequal in length to article 2, with three stout setae (one proximal, one medial, and one distal) on the ventral margin, peduncular article 2 about 1.6 times length of article 3; flagellum shorter than peduncle with 15 articles; accessory flagellum with 2 articles. Antenna 2 densely setose, reaching the end of peduncle of antennae 1; peduncular article 4 subequal in length to article 5; flagellum with 12 articles. Mandible palp, second article about 3 times longer than wide, slightly shorter than article 3 ; article 3 falcate, setose along concave margin, with three long apical setae. Maxilla 1, inner plate subrectangular, with 2 apical plumose setae; outer plate with five stout setae variably cuspidate; palp 2-articulated, article 2 with three apical and three facial setae. Upper and 


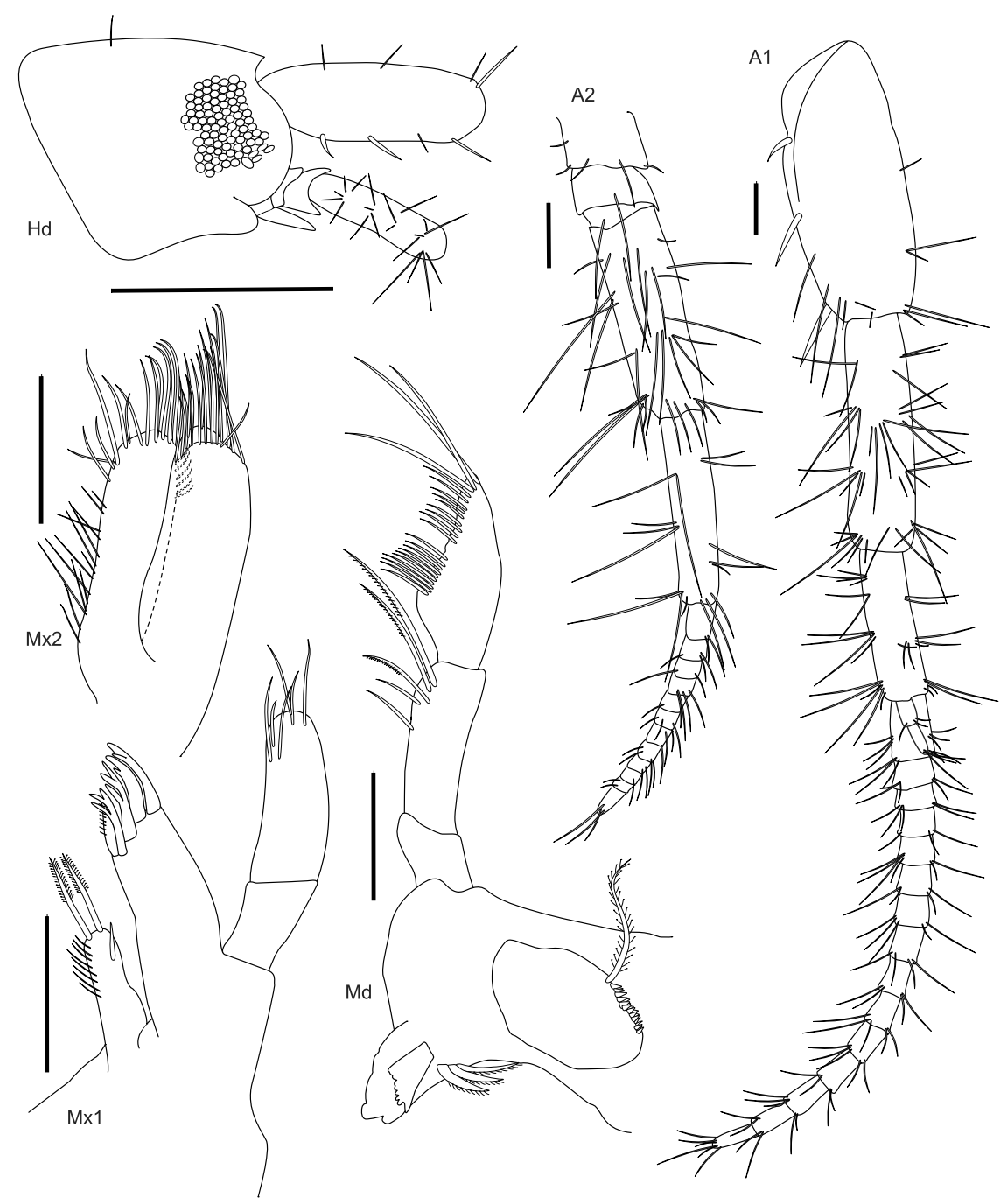

Fig. 1 - Elasmopus souzafilhoi sp. nov. Holotype, male, $5.9 \mathrm{~mm}, 08^{\circ} 21^{\prime} 26^{\prime \prime S}-34^{\circ} 57^{\prime} 22^{\prime \prime} \mathrm{W}$, October $10^{\text {th }}, 2003$, intertidal, MNRJ 22534. Scale bars: $0.5 \mathrm{~mm}$ for $\mathrm{Hd}$; $0.1 \mathrm{~mm}$ for the remains.

lower lip, maxilla 2 and maxilliped with basic characters for the genus.

Gnathopod 1 subchelate; coxa, anteroventral corner produced and rounded, ventral margin beset by small simple setae, with some long slender setae; basis, posterior margin without setae; merus densely setose distally; carpus densely setose ventrally, about 1.5 times longer than wide; propodus with long facial and marginal setae dorsally and ventrally, palm acute, slightly convex, setose, defined by a stout seta, about 0.7 times posterior margin length; dactylus reaching the palmar corner. Gnathopod 2 subchelate; coxa, ventral margin beset with small simple setae, with some long slender setae; basis subrectangular, with four long setae on posterior margin; ischium slightly produced anteriorly; merus with posteroventral corner produced and acute; carpus 1.7 times wider than long, about 0.25 times the propodus length, posteroventral corner slightly produced and setose; propodus suboval, tapering distally, about 1.9 times longer than wide, without medial excavation, posterior margin covered by a dense fringe of long plumose setae, palm acute, not defined by a stout seta, spine, or palmar corner, bearing a subdistal blunt and apically truncated tubercle, with three small stout setae near hinge of dactylus; dactyl elongate and curved, posterior margin slightly sinuous, minutely setose, apically acute. 


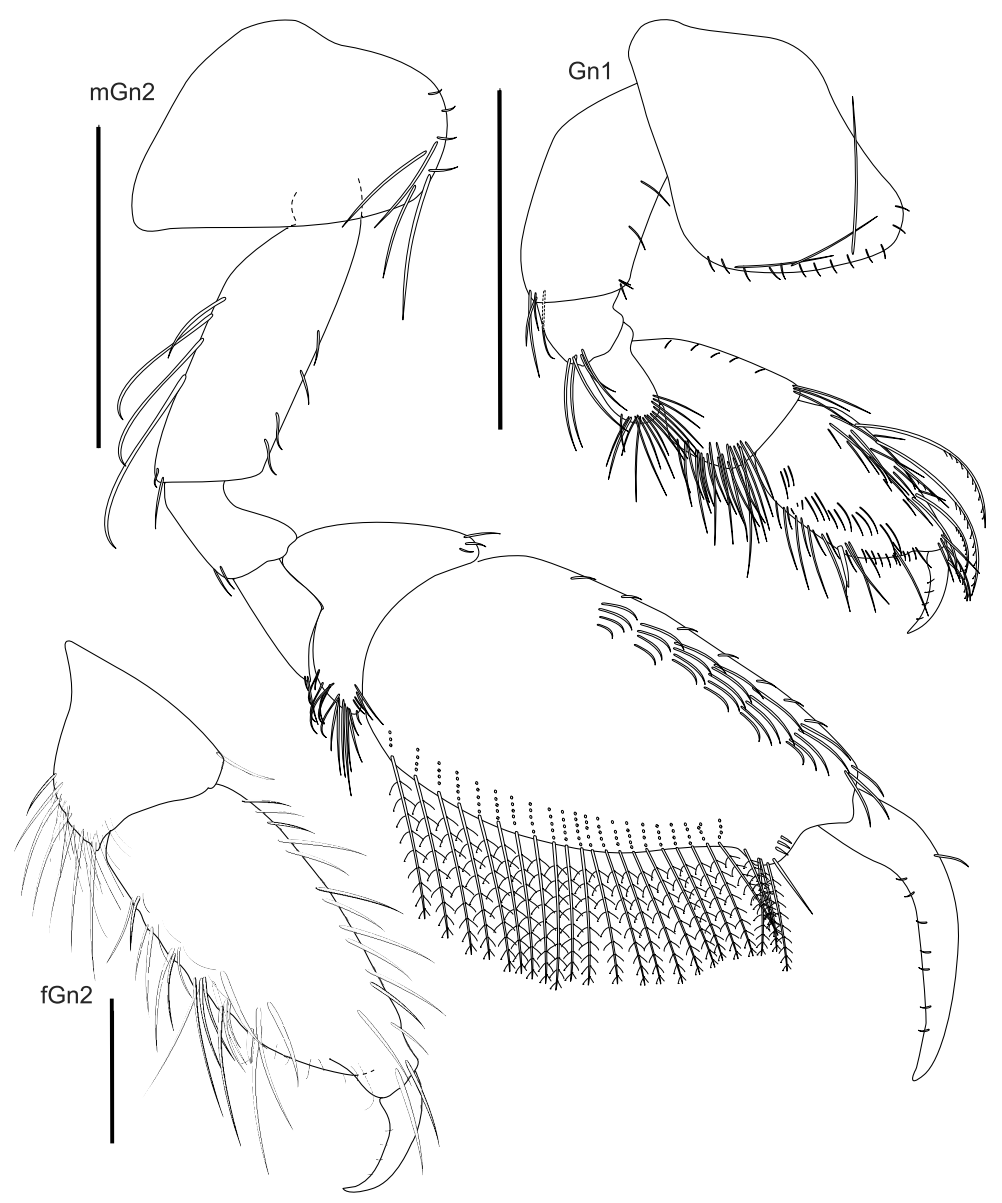

Fig. 2 - Elasmopus souzafilhoi sp. nov. Holotype, male, $5.9 \mathrm{~mm}, 08^{\circ} 21^{\prime} 26^{\prime \prime S}-34^{\circ} 57^{\prime} 22^{\prime \prime} \mathrm{W}$, October $10^{\text {th }}, 2003$, intertidal, MNRJ 22534; paratype, female, $5.7 \mathrm{~mm}$, MNRJ 22536. Scale bars: $0.5 \mathrm{~mm}$.

Pereopod 3, coxa longer than wide (about 1.5 times), ventral margin beset with small simple setae, with some long slender setae; basis with two long setae on posterior margin; merus 1.2 times the propodus length; carpus with six stout setae on posterior margin; propodus with a row of stout setae on posterior margin; dactyl short, about 0.4 times the propodus length, nail present. Pereopod 4 similar to pereopod 3, but coxa 1.1 times longer than wide, with posterior margin slightly excavate. Pereopod 5, coxa wider than long, excavate ventrally, anteroventral lobe slightly produced and rounded; basis posterior margin slightly convex, smooth, with a row of small simple setae, posteroventral lobe slightly produced, subquadrate; merus and carpus longer than wide, posterior margin poorly expanded; dactyl, nail present. Pereopod 6, coxa wider than long, bearing two stout setae posteroventrally; basis, posterior margin slightly convex, smooth, with a row of small simple setae, posteroventral lobe slightly produced, subquadrate; merus and carpus longer than wide, posterior margin poorly expanded; dactyl, nail present. Pereopod 7, coxa small, wider than long, with anterior margin convex; basis, posterior margin convex, almost entirely castelloserrate, posteroventral lobe slightly produced, rounded to subtriangular; merus and carpus longer than wide, posterior margin poorly expanded; propodus 1.6 times the carpus length; dactyl, nail present.

Epimeral plate 1, ventral margin with one perpendicular set of slender setae, posterior margin with one notch, posteroventral corner defined by a short spine, ventral triangular process present. Epimeral plate 2, ventral margin with two perpendicular sets of slender 


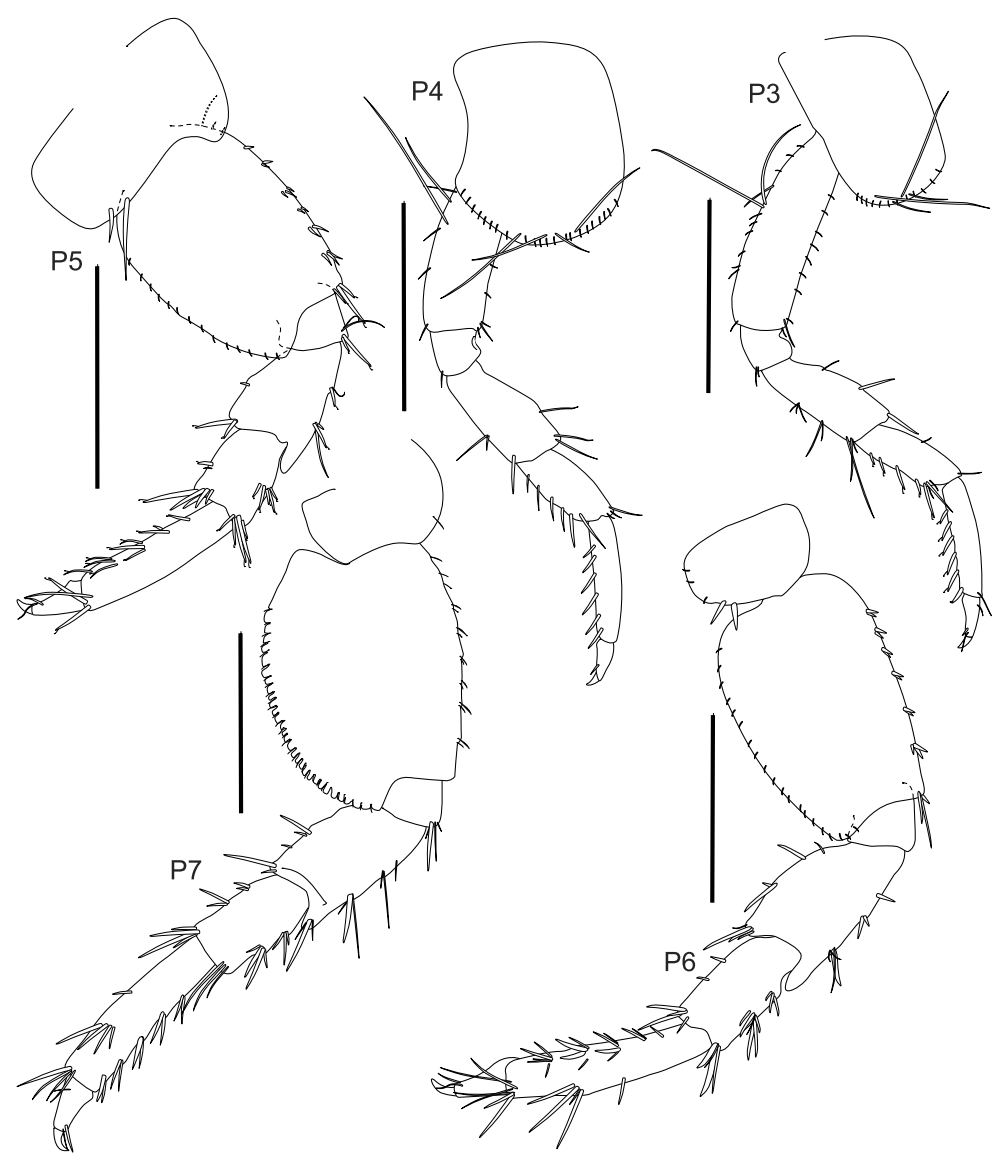

Fig. 3 - Elasmopus souzafilhoi $\mathrm{sp}$. nov. Holotype, male, $5.9 \mathrm{~mm}, 08^{\circ} 21^{\prime} 26^{\prime \prime S}-$ $34^{\circ} 57^{\prime} 22^{\prime \prime}$, October $10^{\text {th }}, 2003$, intertidal, MNRJ 22534. Scale bars: $0.5 \mathrm{~mm}$.

setae, posterior margin slightly serrate, with two notches, posteroventral corner defined by a short spine, ventral triangular process present. Epimeral plate 3, ventral margin with four perpendicular sets of slender setae, posterior margin slightly serrate with five notches, posteroventral corner slightly produced and subacute. Uropod 1, peduncle with basofacial stout seta, without distoventral spur, five stout setae on the inner dorsal and six stout setae on the outer dorsal margins, distodorsal corner with a long curved stout seta in the inner side; inner ramus about 0.8 times as long as peduncle, with three marginal and four apical stout setae. Uropod 2, peduncle dorsodistally with one stout setae on inner margin and two on outer margin; inner ramus about 1.3 times longer than peduncle, with four marginal stout setae and four apical stout setae. Uropod 3, peduncle 1.8 times longer than wide, with one proximal and one distal stout seta ventrally; outer ramus apically truncated, slightly longer than peduncle, with eight apical stout setae, with three sets of long stout setae on the outer margin; inner ramus thinner and slightly shorter than outer ramus, apically truncated, with four apical stout setae, inner margin with two small stout setae. Telson 1.3 times wider than long, deeply cleft (about 65\%), each lobe with one apicolateral cusp well developed reaching the inner distal acute corner, and with three subapical stout setae.

\section{SEXUAL DIMORPHIC CHARACTERS}

Based on paratype female, $5.7 \mathrm{~mm}$, MNRJ 22536. Gnathopod 2, carpus about 1.3 longer than wide and 0.6 times as long as propodus; propodus about 2.4 times longer than wide; palm acute, slightly convex, smooth, with sparse slender setae, about 0.6 times as long as posterior margin, palmar corner defined by a stout seta; dactylus reaching the end of palm. Telson 1.4 times 


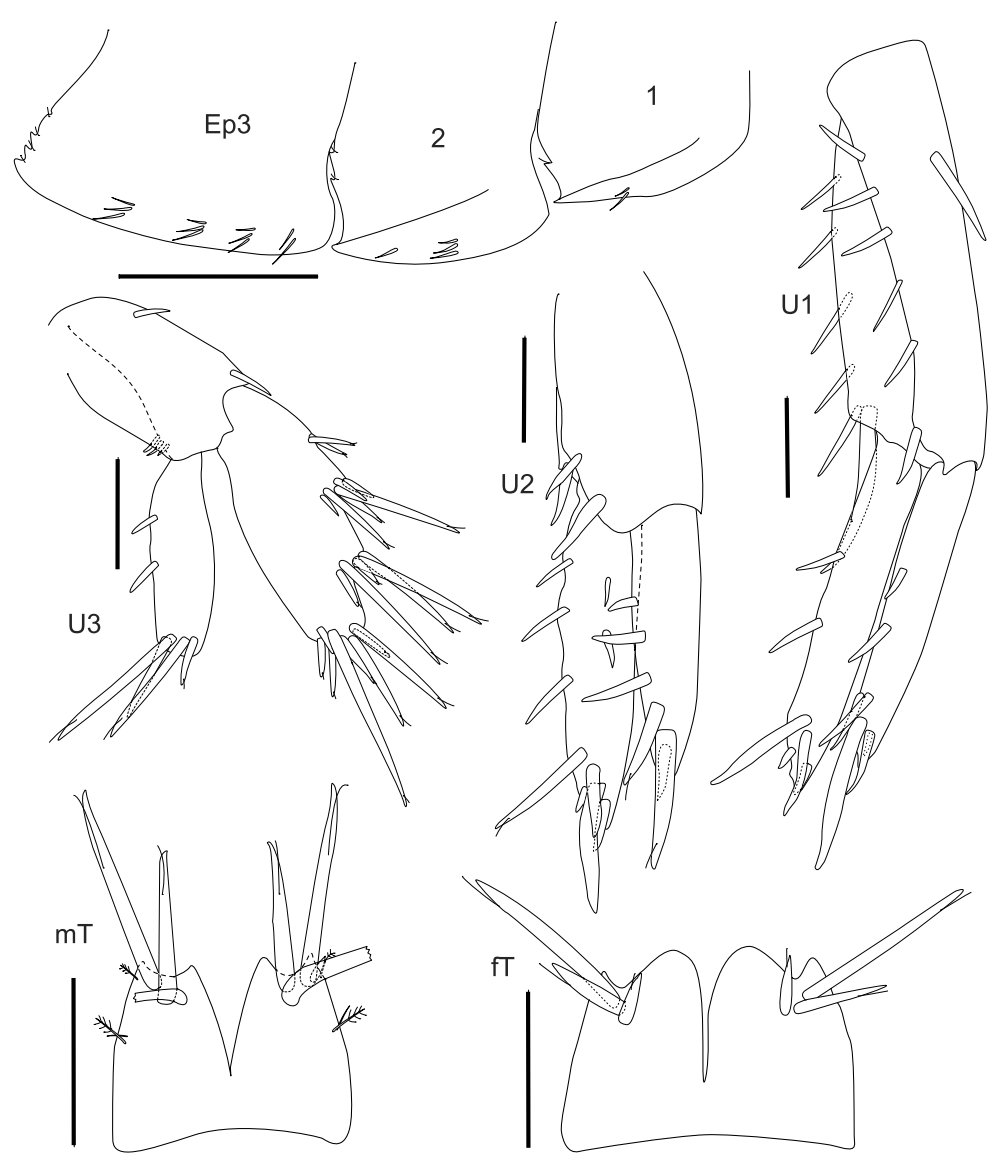

Fig. 4 - Elasmopus souzafilhoi sp. nov. Holotype, male, $5.9 \mathrm{~mm}, 08^{\circ} 21^{\prime} 26^{\prime \prime S}-34^{\circ} 57^{\prime} 22^{\prime \prime}$, October $10^{\text {th }}, 2003$, intertidal, MNRJ 22534; paratype, female, $5.7 \mathrm{~mm}$, MNRJ 22536. Scale bars: $0.5 \mathrm{~mm}$ for Ep1-3; $0.1 \mathrm{~mm}$ for the remains.

wider than long, deeply cleft (about $72 \%$ ), each lobe with one apicolateral cusp well developed but not reaching the inner distal rounded corner, and with three subapical stout setae.

\section{REMARKS}

Elasmopus souzafilhoi sp. nov. is closely related to a group of species characterized by the presence of a very dense fringe of long setae at the posterior margin of the propodus of male gnathopod 2 and the posterior margin of the basis of pereopod 6 and/or 7 castelloserrate (Krapp-Schickel and Ruffo 1990). This group presents an intertropical distribution and is composed by the following ten species: E. canarius; E. crenulatus; E. fusimanus; E. laufolii; E. oaxaquensis; E. pectenicrus; E. serricatus; E. souzafilhoi sp. nov.; E. spinibasus; and
E. yunde. Elasmopus souzafilhoi sp. nov. is very closely related to E. oaxaquensis, from Pacific Mexico, and E. serricatus, from California. Both species present gnathopod 2 with propodus suboval, tapering distally, with a tubercle near hinge of dactylus, and covered by a dense fringe of plumose setae, besides the posterior margin of basis of pereopod 7 castelloserrate, like the new Brazilian species. However, E. oaxaquensis differs from $E$. souzafilhoi sp. nov. in having the propodus of gnathopod 2 with palm defined by a short mediofacial ridge and two blunt teeth in the inner side of the palm, epimeral plate 3 with posterior margin smooth but regularly beset with four small slender setae, and uropod 3 with peduncle as long as wide, and outer ramus as long as peduncle. The new species presents propodus of gnathopod 2 with palm not defined, and without teeth or any processes in its inner side, epimeral plate 3 
with posterior margin slightly serrate with five notches, and uropod 3 with peduncle almost twice longer than wide, and outer ramus slightly longer than peduncle. Similarly, E. serricatus differs from E. souzafilhoi sp. nov. presenting the propodus of gnathopod 2 with a middle palmar tooth near the hinge process, and palm defined by a small ridge, but in this species bearing a stout seta. Elasmopus serricatus also presents epimeral plate 3 with posterior margin slightly serrate, and uropod 3 with inner ramus shorter and narrower than outer ramus. On the other hand, E. serricatus differs from E. souzafilhoi sp. nov. in having telson with apical margin truncate bearing 5-8 stout setae, while the new species presents telson apically truncate with cusps in male, or inner corner rounded in female, with three subapical stout setae in each lobe. Among the Brazilian castelloserrate species, hitherto only E. pectenicrus and E. fusimanus are recorded to Brazilian waters, besides the new species described in this paper. Elasmopus souzafilhoi sp. nov. is closely related to E. pectenicrus in having gnathopod 2 with propodus suboval, tapering distally, palm not defined, with a tubercle near hinge of dactylus, and covered by a dense fringe of plumose setae. The original description and illustrations in Bate (1862) are not clear about the shape of this tubercle on the palm of gnathopod 2 of E. pectenicrus. Nevertheless, Appadoo and Myers (2003) redescribed this species with material from Mauritius, Indian Ocean, making clear that this process in E. pectenicrus is sharp and subacute. Besides this, the new species presents the basis of pereopod 6 with posterior margin not castelloserrate, not abruptly narrowing, with posteroventral corner not produced and subquadrate, and the posterior margin of basis of pereopod 7 castelloserrate. On the other hand, Elasmopus pectenicrus presents the basis of pereopod 6 with posterior margin castelloserrate, abruptly narrowing distally, and its posteroventral corner is produced, rounded, and serrate. The new species is also very similar to E. fusimanus by the gnathopod 2 with palm not defined, a tubercle near hinge of dactylus, and posterior margin covered by a dense fringe of plumose setae, besides the castelloserrate posterior margin of the basis of peropod 7. Nevertheless, in $E$. fusimanus the propodus of gnathopod 2 does not taper so distally, being almost subrectangular, and the distal process near hinge of dactylus is broadly rounded. In the new species the propodus of gnathopod 2 strongly tapers distally, and the distal process near hinge of dactylus is slightly truncate apically. Finally, in $E$. fusimanus the basis of pereopod 7 is poorly expanded posteriorly and the posterior margin is castelloserrate only at its distal part, while in E. souzafilhoi sp. nov. the basis of pereopod 7 is broadly expanded posteriorly and its posterior margin is almost entirely castelloserrate.

\section{GEOGRAPHIC DISTRIBUTION}

Known only from the type locality, Suape Beach, Santo Agostinho Cape, Pernambuco State coast, Brazil.

\section{BATHYMETRIC RANGE}

Collected at the intertidal zone.

\section{KEY TO SPECIES OF Elasmopus FROM BRAZILIAN WATERS (ONLY MALES)}

1. Epimeron 3 produced into an acute spine; basis of pereopod 5 with posterior margin concave ........2

- Epimeron 3 not produced, posterior margin sometimes with short denticles; basis of pereopod 5 with posterior margin not concave ....................... 3

2. Gnathopod 2, propodous without a row of tubercles and perpendicular rows of long setae on inner face, palm acute, shorter than posterior margin of propodus, palmar corner defined by 2 spines ..................... .... Elasmopus karamani Souza-Filho and Senna, 2009 - Gnathopod 2, propodous with a row of tubercles and perpendicular rows of long setae on inner face, palm extremely acute, longer than posterior margin of propodus, not defined by spines or stout setae ............. ......Elasmopus lejeunei Souza-Filho and Senna, 2009

3. Gnathopod 2, palm not defined by spines, without any process near hinge of dactylus or spine $\ldots . \ldots \ldots \ldots$. ............. Elasmopus brasiliensis (Dana, 1852)

- Gnathopod 2, palm defined or not, with a process near hinge of dactylus ......................... 4

4. Gnathopod 2, palm with a strong spine defining palmar corner, with a process apically truncate near hinge of dactylus, posterior margin not densely setose ......... Elasmopus longipropodus Senna and Souza-Filho, 2011 
- Gnathopod 2, palm not defined by spines, with a process near hinge of dactylus, posterior margin densely

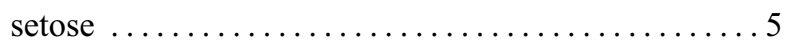

5. Gnathopod 2 with an acute or truncate process near hinge of dactylus; pereopod 7, posterior margin of basis not castelloserrate $\ldots \ldots \ldots \ldots \ldots \ldots \ldots \ldots 6$

- Gnathopod 2 with a rounded or apically truncate process near hinge of dactylus; pereopod 7, posterior margin of basis castelloserrate $\ldots \ldots \ldots \ldots \ldots \ldots \ldots 7$

6. Gnathopod 2, propodus tapering distally, palm with a distal shallow abruptly truncate process near hinge of dactylus and a subdistal outwardly deflected obtuse spine; pereopod 6, posterior margin of basis not excavate and not castelloserrate; pereopods 3-4, posterior margin of dactyli spinose; pereopods 5-7, anterior margin of dactyli spinose

.......... Elasmopus spinidactylus Chevreux, 1908

- Gnathopod 2, propodus suboval, palm with a distal subacute triangular process near hinge of dactylus; pereopod 6 , posterior margin of basis excavate and castelloserrate; pereopods 3-7, anterior and posterior margins of dactyli not spinose ...... Elasmopus pectenicrus (Bate, 1862)

7. Gnathopod 2, propodus not tapering distally, subrectangular, palm with a broadly rounded process near hinge of dactylus; pereopod 7, posterior margin of basis distally castelloserrate (only on its distal third part) ..........Elasmopus fusimanus Oliveira, 1951

- Gnathopod 2, propodus tapering distally, palm with a rounded apically truncate process near hinge of dactylus; pereopod 7, posterior margin of basis almost entirely castelloserrate ....... Elasmopus souzafilhoi sp. nov.

\section{ACKNOWLEDGMENTS}

The author is very grateful to Jesser F. Souza Filho (Universidade Federal de Pernambuco) by providing the material examined and for his valuable comments on the manuscript. Special thanks to Adriano Kury (Museu Nacional, Universidade Federal do Rio de Janeiro) for improvements in the English version of the manuscript, and Luana Lins (Museu Nacional, Universidade Federal do Rio de Janeiro) for advice on digital illustrations. This study was financially supported in part by Coordenação de Aperfeiçoamento de Pessoal de Nível Superior (CAPES).

\section{RESUMO}

Uma nova espécie Amphipoda do gênero Elasmopus Costa, 1853 é descrita com base em material coletado da zona entremarés de um costão rochoso, próximo ao Porto de Suape, costa do estado brasileiro de Pernambuco. A nova espécie pode ser reconhecida pelo própodo do gnatópode 2 suboval, estreitando-se de forma suave distalmente, margem palmar não definida por uma cerda grossa, espinho, ou ângulo palmar, com um tubérculo subdistal não agudo, margem posterior coberta por uma franja densa de cerdas plumosas, e margem posterior da base do pereópodo 7 castelosserrado. Esta é a nonagésima quinta espécie do gênero Elasmopus descrita ao redor do mundo, o mais diverso gênero na família Maeridae Krapp-Schickel, 2008, e a oitava espécie registrada para as águas brasileiras. É fornecida também uma chave de identificação para as espécies brasileiras de Elasmopus.

Palavras-chave: Brasil, Elasmopus souzafilhoi sp. nov., Gammaridea, entre-marés, Pernambuco, taxonomia.

\section{REFERENCES}

ApPAdoo C AND Myers AA. 2003. The genus Elasmopus Crustacea: Amphipoda: Melitidae) from Mauritius (Indian Ocean) with description of five new species. Rec Aust Mus 55: 61-84.

BARNARD JL. 1965. Marine Amphipoda of atolls in Micronesia. Proc US Natl Mus 117(3516): 459-551.

BATE CS. 1862. Catalogue of the specimens of amphipodous Crustacea in the collections of the British Museum, London. Br Mus Nat Hist 4: 1-399.

COLEman CO. 2003. "Digital inking": How to make perfect line drawings on computers. Org Divers Evol 3 (Electr Suppl 14): 1-14.

KARAMAN GS. 1982. Gammaridae. In: RufFo S (Ed), The Amphipoda of the Mediterranean, Part 1, Gammaridea (Acanthonotozomatidae to Gammaridae). Mem Inst Oceanogr (Monaco) 13: 245-364, figs. 166-243.

KRAPP-SCHICKEL T AND JARRETT NE. 2000. The amphipod family Melitidae on the Pacific coast of North America: Part II. The Maera-Ceradocus complex. Amphipacifica 2(4): 23-61.

KRAPP-SCHICKEL T AND RUfFO S. 1990. Marine amphipods of the Canary Islands with description of a new species of Elasmopus. Misc Zool 14: 53-58.

KRAPP-Schickel T AND RUfFo S. 2000. The Maera quadrimana - complex (Crustacea Amphipoda, Melitidae) demands a new concept: Quadrimaera $n$. gen. (with 
description of three new species from Western Atlantic). Boll Mus Civ Stor Nat Verona 24: 193-214.

POORE AGB AND LOWRY JK. 1997. New ampithoid amphipods from Port Jackson, New South Wales, Australia (Crustacea: Amphipoda: Ampithoidae). Invertebr Taxon 11: 897-941.

Senna AR AND Serejo CS. 2007. Two new species of Quadrimaera (Crustacea: Amphipoda: Melitidae) from Atol das Rocas, Brazil. Zootaxa 1593: 55-67.

SenNa AR AND Souza-Filho JF. 2011. A new species of the Elasmopus rapax complex (Crustacea: Amphipoda: Maeridae) from Brazilian waters. Cah Biol Mar 52: 5770 .
Souza-Filho JF And Senna AR. 2009. Two new species of the genus Elasmopus Costa, 1853 (Amphipoda: Gammaridea: Maeridae) from off the Northeast Brazilian coast. Zootaxa 2301: 55-68.

WATLING L. 1989. A classification of crustacean setae based on the homology concept. In: FUnCTIONAL MORPHOLogy of FeEding and Grooming in CRUstacea. Crustacean Issues, Rotterdam: A.A. Balkema, p. 15-26. 